\title{
POLITICAL COMMUNICATION OF JAWARA IN THE ROAD INFRASTRUCTURE PROGRAM AND POVERTY ALLEVIATION IN PANDEGLANG DISTRICT, INDONESIA
}

\author{
Fitriyah Neka* \\ Study Program of Communication Science, Faculty of Social and Political Sciences, \\ Sultan Ageng Tirtayasa University, Indonesia \\ Sarwoprasodjo Sarwititi, Sjaf Sofyan, Soetarto Endriatmo \\ Department of Communication and Community Development Sciences, \\ Bogor Agricultural University, Indonesia \\ *E-mail: neka fitriyah@untirta.ac.id
}

\begin{abstract}
Pandeglang is one of the districts in Indonesia's Banten Province with high poverty rates and uneven road infrastructure conditions. This issue has an impact on the difficulty of people to live more prosperously due to economic obstacles and inadequate access. This study aims to describe the political communication of Jawara in the Jamsosratu poverty alleviation and road infrastructure program. This study uses a qualitative method and multiple case study design using Habermas' communicative action theory. Data is collected through in depth interviews and participatory observation techniques, both for key informants and informants. In implementing participatory observation techniques, the author directly interacted with informants and key informants both in formal forums and in day-to-day informal forums. The informants are selected using purposive sampling. The key informants are jawara who are directly involved in road infrastructure program, while key informants who are related to Jamsosratu program is people who understand the research problem but are not directly involved. The author, finally, interviewed 14 key informants and 8 informants. The results showed that the champion was a determinant factor in regional development. Jawara make political communications with the government, the community is also political elite. There are two typologies of Jawara: traditional and modern Jawara. The political communication of traditional jawara leads to consensus regarding community empowerment at micro level, while the political communication of modern jawara leads to the consensus of development at macro level. lluksioner communication orientation is dominated by traditional jawara, while proluksioner communication orientation is dominated by modern jawara.
\end{abstract}

\section{KEY WORDS}

Communication, political communication, jawara, local elite, development, poverty alleviation.

Pandeglang Regency is regency in Banten Province. Since the enactment of regional autonomy in 2000, development problems in Pandeglang Regency still revolve around the problem of poverty (Sumiyati 2019). Development regulations made by the local government, even through grants for the poor, the empowerment and infrastructure development still do not give significant impacts on the economic growth in Pandeglang, thus poverty problems remains. The poverty rates keep increasing, where the poverty rate in 2017 by 501.78 increased from 115.9 in March 2016 (Central Statistics Agency of Pandeglang 2018).

The road infrastructure program has been implemented since the New Order era, starting in 1965 until present, but road construction in Pandeglang Regency has not been evenly distributed. In 2019 the construction of 21.852 kilometers concrete road, improvement of approximately 4.828 kilometers hot-mix roads, and construction of 26.68 kilometers there are still several roads than cannot be implemented because of the lack of budget (Public Works Department and Public Housing 2019).

From socio-cultural perspective, Pandeglang is an agrarian society with the dominance of jawara in regional development activities. Jawara as local ethnicity is a sub-culture that 
has the power to determine people's attitudes and behavior in development. Nuris (2008) stated that this not only because of their position, political office, but more because of their charisma, inherent myths, knowledge, and experience.

The dynamics of local politics in Pandeglang have already systemized to strengthen the position of jawara. Easy bureaucracy access is given to jawara so they could enact their development programs (Sutisna, 2017). This condition occurs not only because Jawara has special and powerful position but also because of their existence is embedded in every development ideals or programs. Nowadays, many jawara transformed as politicians, bureaucrats, and entrepreneurs to respond the dynamic of local politics (Bandiyah, 2012). This transformation also strengthens the position and role of Jawara in development programs (Muslim, et al 2015).

One of the regulations and development directions made by local government during post-reform period (2001-2019) is to address poverty alleviation. The purpose of Jamsosratu (Jaminan Rakyat Banten Bersatu/Insurance for Banten People's Program) program is overcome poverty through compulsory basic education for 6 years and also health facilitation. The grantee of this program is called as RTSM (Rumah Tangga Sasaran Miskin/Targeted Poor Household) and total of the grantees have been fluctuative not because of the decrease of poverty rate but because of limited budget (Social Service Pandeglang Regency 2018). The Jamsosratu program has been implemented for 18 years but have not give any significant impact in decreasing povery rate (Bachruddin, 2019). The figure below explains the trend of RTSM in Pandeglang Regency.

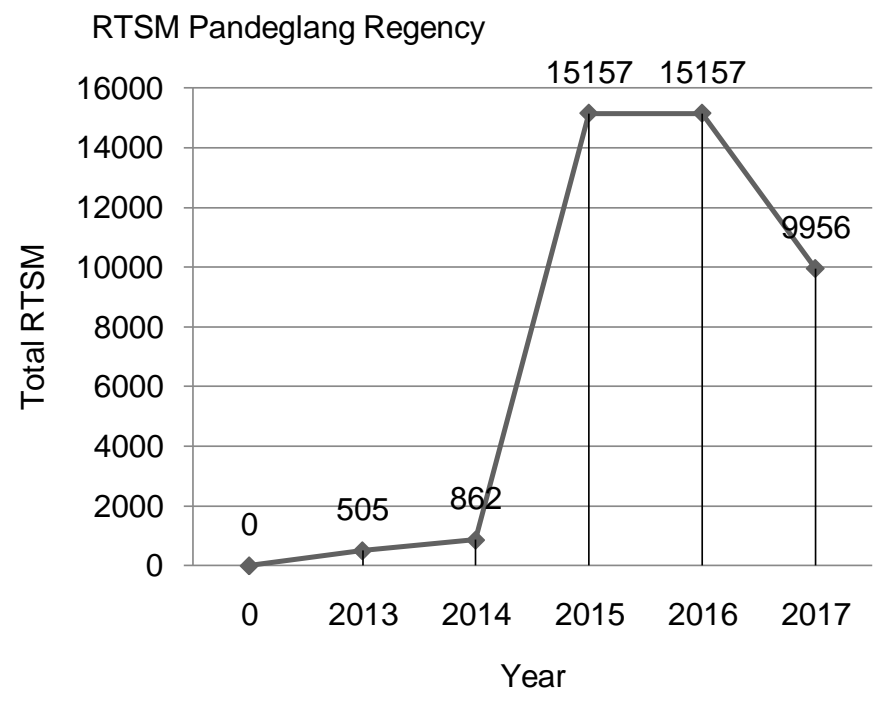

Figure 1 - Jamsoratu Trend from 2013-2017

The high rate of RTSM indicates that poverty is still a significant problem in Pandeglang. This condition occurs because of the top-down approach in implementing development and poverty alleviation program and still put local people as the object, not the subject of development. Jawara as the local elites have the capability and political communication capacity to make local people become the subject of development (Deswimar 2014, Kusumawarta and Sjaf, 2018). However, the problem is whether the jawara as local elites could support poverty alleviation and development program.

Based on these conditions, the purpose of this study is to understand political communication of jawara in poverty alleviation program and road infrastructure in Pandeglang Regency. To ansert this question, the author use communicative action theory by Habermas. Murtagh et al (2016) stated that Habermas defines communicative action as an act that puts rationality to build mutual understanding, there's no power domination, and everybody have a chance to talk and is equal in a dialogue. Argumentation and rationality are prerequisites in building mutual understanding in communicative actions. 


\section{METHODS OF RESEARCH}

This study uses a qualitative approach. Lincoln (2017) stated that qualitative is a place for a variety of methodologies and research practices. The multiple case study method is used to explore and trace information and compare data related to jawara political communication in the Jamsosratu program and the road infrastructure program. The study was conducted in Pandeglang Regency for 6 months, from October 2018 until March 2019.

Data is collected through in depth interviews and participatory observation techniques, both for key informants and informants. In implementing participatory observation techniques, the author directly interacted with informants and key informants both in formal forums and in day-to-day informal forums. Occasionally, the author was asked by informants to provide views about poverty at micro and macro level. The formal forum consists of Musdus (Musyawarah Dusun/Kampong Dialogue Forum), Musdes (Musyawarah DesaVillage Dialogue Forum), Musrenbang at village level (Musyawarah Perencanaan Pembangunan Dialogue Forum of Planning Development), Musrenbang at subdistrict level, and Musrenbang at district level.

The informants is selected using purposive sampling. The key informants are jawara who are directly involved in road infrastructure program, while key informants who are related to Jamsosratu program is people who understand the research problem but are not directly involved. The author, finally, interviewed 14 key informants (5 jawara; 3 head of subdistricts/camat from Saketi, Cimanuk, and Menes; 2 entrepreneurs, assistant and 3 grantees) and 8 informants ( 6 head of village from Ciandur, Purwaraja, Kananga, and Menes and 2 community public figure).

After analysis and data reduction process, data regarding jawara political communication were gathered. The data includes message of jawara, argumentation from jawara in formal and informal meeting, and also local people's responses. Three emergence themes were founded in this research to answer the purpose of this study, which are: (1) jawara's political communication phenomenon; (2) jawara's orientation of political communication; and (3) model of jawara's communicative action.

\section{RESULTS AND DISCUSSION}

Jawara was originally represented as a group with physical martial abilities (Tihami, 2012). Irfani (2018) stated that jawara position creates a sub-culture within the dominant culture of Banten's people. Jawara represents a group that has norms, values, and unique perspective on life. Hudaeri (2003) stated that jawara phenomenon as a social context refers to its characteristics, specific behavior, and access they gained as jawara.

Jawara, in this study, is divided into two typologies, traditional jawara and modern jawara. The role of traditional jawara with its physical martial abilities act as a safety/security forces while modern jawara acts in the business and local politics in Pandeglang Regency. Jawara in Pandeglang is incorporated in an organization called BPPKBB (Badan Pembinaan Potensi Keluar Besar Banten/Development Agency of Banten's Extended Family) whose network is centralized in Jakarta and spreads to various regions in Indonesia.

The activities of modern jawara are concentrated in the business and political arena which strengthens their existence in government circles. There are values and views on life that solidify between jawara. Those concepts are 'pantang mundur' (never retreats), 'maju terus and bersaing' (keep going and compete); and 'hidup untuk menang' (life is for winning). These slogans act as a spirit that internalized their jawara characteristics. The characteristics of jawara are more pronounced when jawara are incorporated in KADIN (Kamar Dagang Indonesia/Indonesian Chamber of Commerce), GAPINDO (Gabungan Pengusaha Indonesia/Assocation of Entrepreneurs in Indonesia), HIPMI (Himpunan Pengusaha Muda Indonesia/Association of Indonesia's Young Entrepreneurs), and other organizations that work on several road infrastructure development projects by using local government budget. Wijaya Contractor, Althaf Maestra Pratama, and Berdikari Jaya are companies that have 
affiliations with jawara and where the members also join entrepreneurs' organization in Pandeglang.

Unlike modern jawara, traditional jawara do not have access to local business and politics. They focused as village neighborhood safeguard. Siskamling (Sistem Keamanan Lingkungan/Neighborhood Safety System) and traditional market security are places where traditional jawara actively act their roles. Because of this role, traditional jawara is trusted by community, especially in safety aspects. However, traditional jawara are also active in empowering the community, hence traditional jawara have influence to exercise social control over local people activities.

In some observations, traditional jawara are active in the Siskamling activity, where the management of the Siskamling is also managed by the BPPKB. For example, jawara enact the village security by optimizing the Siskamling function, securing religious activities and cultural activities such as those in the villages of Kananga, Menes, Purwaraja and Ciandur. Traditional jawara also dominate the security in traditional markets such as markets in the Menes District, Saketi District and in Cimanuk District. To secure the traditional market, Jawara manage the parking security, security for theft, and market cleanliness.

Other things that distinguishes traditional jawara and modern jawara is their interest in overcoming poverty and community empowerment. Traditional jawara intensively empowers local people and support the poverty alleviation programs through by establishing the Jamsosratu Mandiri Sakti Cooperative in Saketi District. The cooperative specializes in capital micro-enterprise assistance programs and is given evenly to Jamsosratu grantee recipients as business assistance. The type of business undertaken by the grantee is business of door-to-door cake selling. This effort really helps in increasing family income, so that in the future the local people can have better live and out of poverty.

Political communication is a communication that involves political messages from political actors relating to government power and policies (Oktarina and Sarwoprasodjo, 2018). The problem of poverty alleviation through Jamsosratu is Jawara's medium in empowering local people. The political communication played by the jawara has different characteristics and political orientations. For traditional jawara, their political communication tends to shut themselves from political and development issues at the macro level, as stated by an jawara informant: "Abah is not interested in political issues, politics is complicated and do not give any merit” (Jy).

Modern jawara has different perspective compare to traditional jawara. For modern jawara, overcoming poverty, road infrastructure, and development issues are closely related to political issues at macro level. Therefore modern jawa see politics as a medium of struggle, where politics has become one of the ways in realizing their aspirations and ideas of development for society. A modern jawara stated that: "Pandeglang community can be free from poverty if the poverty budget is increased, if community proposed to build roads, then roads can be build. Let's struggle together to realise these programs (Ohm). This kind of discourse is the way-of-life for modern jawara as it is socialized through talks and dialogues with the political elite and also the community.

The strength of the traditional jawara lies in the local people's commitment which impacted the freedom of jawara in providing facilitation for community empowerment. The political power of modern jawara, lies in the organizations they owned and entrepreneurs organizations which facilitate them, such as BPPKBB, GAPINDO, KADIN and HIPMI. Some differences in political communication between traditional jawara and modern jawara: in the musdus held in the villages of Menes, Kananga, Purwaraja and Ciandur, traditional jawara raised the problem of Jamsosratu implementation and discussed their proposed solutions. Eventhough Jamrsosratu is not manage at village level, it's still have to be discussed by village's leaders, jawara, and also the local people at village level. As an informant stated: "there are a lot of poor people who have not received Jamsosratu grants, how this could happen? The poor people need to be facilitated and also empowered, grantee or not" (Znl).

In contrast, the modern jawara who expressed his views in the Musrenbang in Menes District and in the OPD (Organisasi Perangkat Daerah/Regional Apparatus Organization) forum in the Agency of Social Service of Pandeglang Regency: "The problem of poverty, 
Jamsosratu, and the road infrastructure development is hard to be solved if there are no one who struggles it in DPD (Dewan Perwakilan Daerah/Local Representative Assembly). Let's have an approach so that representatives of local people could understand what local people have gone through" (Kt). This political approaches or discourses become the spirit that underlies the thoughts and attitudes of the modern jawara.

Figure 1 below illustrates the orientation of jawara political communication in the Jamsosratu issue and poverty alleviation.

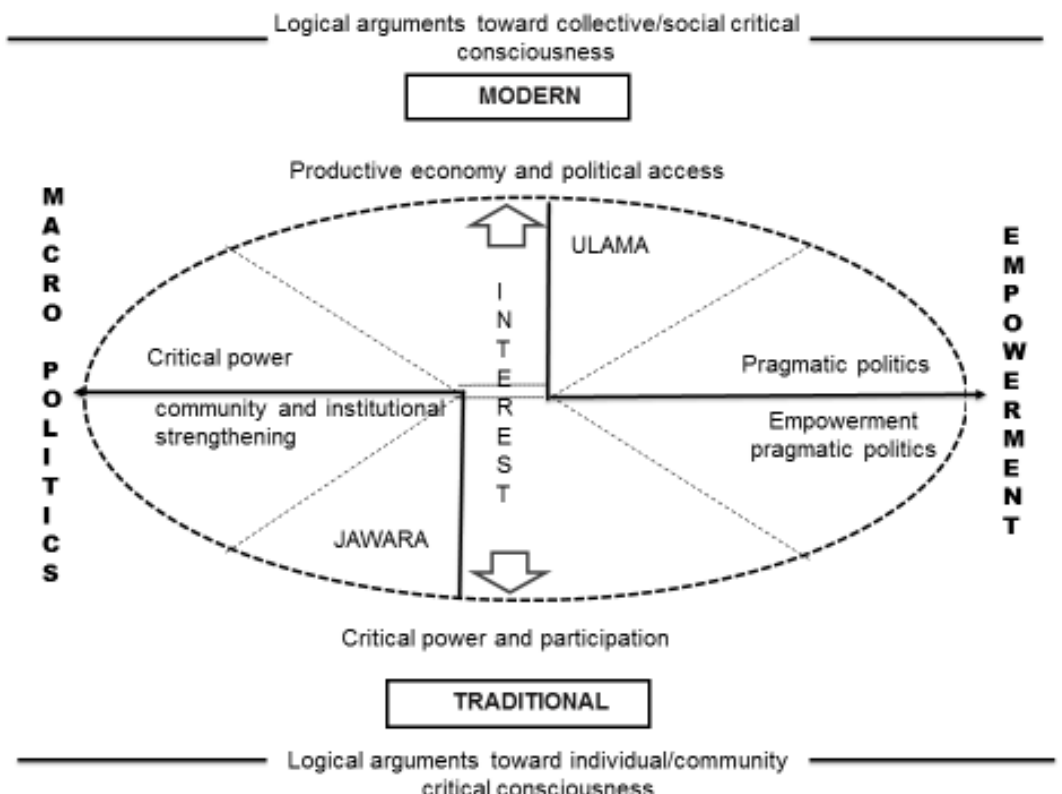

Figure 2 - Jawara's orientation of political communication

There are two Jawara's orientations of political communication in development. The orientation of traditional jawara in development is more focused on community empowerment at the micro level since they are closer to people's daily activities and always in work within the community. For example, traditional jawara and local people work together to build village cooperative and to clean the roads and mosques. Traditional jawara were also the initiators of the village cultural expo week, as seen in Ciandur and Kananga Villages. The cultural expo is a long mulud (religious ceremony) which consists of parade of decorations carried out independently by local people where they distributed food for free to poor people.

Referring to Government Regulation No.45 of 2017 about community participation in organizing regional development, it is stated that the construction of road infrastructure, especially in village or between villages, have to involve local people. In the arena of road infrastructure development, modern jawara as community elites have more domination of power than traditional jawara. This happened because modern jawara is directly related in business sphere and has the competence in implementing the program. Modern jawara in addition also have the capital and they are incorporated in KADIN, GAPINDO, and HIPMI which facilitates the process of working on the project. CV. Sinar Kaduhejo Ciptakarya, CV. Wijaya Contractor, CV. Althaf Maestra Pratama, CV. Berdikari Jaya are companies affiliated with jawara in the implementation of their projects.

Models of jawara political communication in the case of the Jamsosratu program and the road infrastructure program are divided into three models of communicative actions: teleological actions, normative actions, and dramaturgic actions. Teleological refers to jawara's efforts in building agreements with government apparatus and local people both in formal and informal meetings. In a Musdus (formal meeting) at Desa Menes, the jawara conveyed his thoughts to build mutual understandings: "there are no poor people in this world. Let's think about this together so this could help poor local people, whether through grants or poor local people participation in village programs" (Ant). This statement is followed 
by discussion about solutions or alternatives in overcoming poverty problems. It was agreed that the solution for poverty alleviation was by giving grants accompanied by assistance or facilitation from the village apparatus.

The normative action of jawara refers to the talk and argumentation of jawara in carrying out the previous agreements. One of these actions is implemented when jawara was involved in a socialization of Jamsosratu program and road infrastructure to the local people. The jawara listened to the problems voiced by the community, such as anxiety about damaged road, the number of poor people who have not received grants, the confusion of residents in developing their businesses, or religious issues faced by local people. This situation provides an opportunity for jawara to communicate politically. For example discourse in local people discourse is formed to approve the road improvement programs that already approved by village apparatus. As showed in this quotation: "Let us support this program by taking it to the streets to work together. The project is directly controlled by the village, if the road is good we will receive the benefits" ( $\mathrm{Znl})$. This is the argument voiced by jawara which happened in a dialogu about village road construction in Kananga Village and Purwaraja Village which involved a wider local people. Jawara invited and motivated the local people to participate in road construction projects.

The dramaturgic act refers to modern jawara political communication in showing his self-image to build positive impression by expressing their subjectivity. In this dramaturgic act, jawara's political communication tends to be manipulated and distorted. The message conveyed is not to build mutual understanding and to enact agreements, but rather for building positive and gain popularity. On several occasions, the jawara strengthened each other's opinions to get support from local people in the election of regional heads (Pilkada) or Pilkades (village head elections).

Another dramaturgic act from jawara's political communication is showed through political support for particular candidates under the pretext of regional development and the progress of society. To serve this interest, there are many jawara who are active as vote gathers and campaign teams. Jargons such as 'pembangunan untuk rakyat' (development for the people), 'pembangunan untuk kesejahteraan masyarakat' (development for the welfare of people), and 'pembangunan untuk keadilan' (development for justice) are made by jawara and shown in banners or while campaigning. In an informal meeting with local people, jawara usually said: "please choose the legislative candidate No.1 of PKS (Partai Keadilan Sejahtera, a political party from Indonesia). The person is really trustworthy and responsible to the local people and has shown care to poor people" (Asp). The implication of this situation is the disappearance of critical argumentation and rationality.

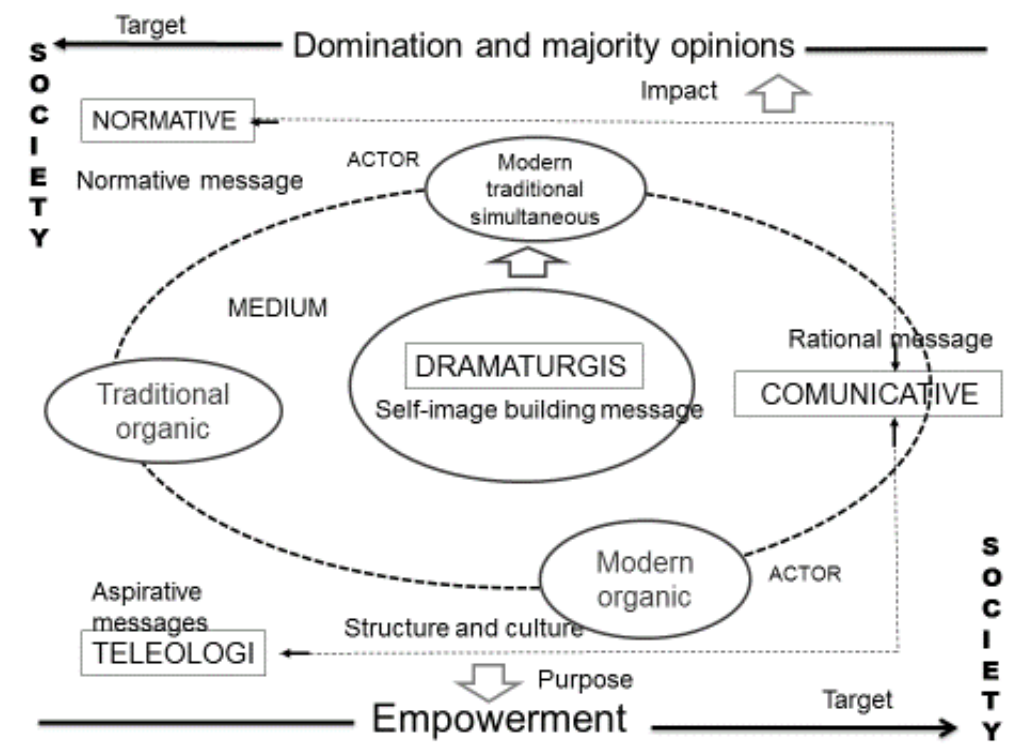

Figure 3 - The dominant model of jawara's communicative actions 
Another interesting finding in this political communication process is ulama's and jawara's orientation of the political communication. The theory of communicative action distinguishes two communication orientations: iluksioner and proluksioner. lluksioner refers to a communication activity that emphasizes the processes and understanding, while proluksioner is a communication activity for achieving results or building consensus.

The orientation of jawara political communication can be traced with these two models. Traditional jawara group emphasize the iluksioner side in its messages, while modern group more focused on "proluksioner" or successfulness and output of activity. Communication activity of traditional jawara is more focused on having daily interaction with local people, spending time together, and giving local people understanding for the sake of development and empowerment. The role of traditional jawara is assisting and facilitating local people so that they could be free from poverty through managing cooperative. Managing cooperative could drive the solidarity of people, where people work together or collectively.

Traditional jawara build an understanding that fit with existing norms and values. For traditional jawara, this is a social strategic effort to raise critical consciousness among local people. However, to raise consciousness of local people maximum effort, such continous assistance and facilitation, is critically needed. This kind of communication orientation is usually found in informal meetings or various meetings between jawara and local people. For example, this group is active on giving explanation about the development of a more prospective cake and snake micro-business.

In contrast with traditional jawara, the orientation of jawara's political communication aims to proliferation model, where communication activities have to reach the objectives in short time. Modern jawara is more oriented to results or output, since they see that this support the idea of building mutual understanding. For example, this group is heavily involved in infrastructure development programs, macro politics, and practical politics that have direct economic value and benefits. The results achieved can be in the form of political access, institutional strengthening, economic benefits, the distribution of development projects and/or being involved in various development programs.

The achievement of jarawa can be from its economic establishment and their popularity in BPPKBB. BPPKBB is a labor supplier for PT. Agung Podomoro Group Tbk in Indonesia. This situation leads to a more elitist modern jawara with lack of concern to poverty alleviation at micro level. Instead, modern jawara is more focused on distributing labor to various big companies. Modern jawara are also affiliated with political parties to win a legislative election. The involvement of jawara in the political arena is intended to carry out a political approach in developing regional development programs at a macro level.

\section{CONCLUSION}

The jawara political communication in the infrastructure program and the Jamsosratu program is mapped by the typology of the jawara: traditional and modern jawara. The political communication of traditional jawara leads to a consensus for community empowerment on a micro level, while the political communication of modern jawara is more directed at the consensus of development in the macro level. The difference between traditional and modern jawa is not only due to political orientation and communication activities but also due to its access and communication network. In the case of communicative action, both traditional and modern jawara are using the communicative action model: teleological, normative, and dramaturgic. For traditional jawara, the orientation of political communication refers to the iluksioner action that emphasizes on building understanding, while the modern jawara refers to the proluksioner model which emphasizes on results.

\section{REFERENCES}

1. Bachruddin, D. T. (2019). Implementasi Program Jamsosratu dalam Bidang Kesehatan di Kabupaten Pandeglang. JIPAGS, 2(1). 
2. Bandiyah. (2012). Evolusi Jawara di Banten (Studi Evolusi Dari Bandit Menjadi Pejabat). Jurnal Udaya. 9(3).

3. Central Statistics Agency of Pandeglang 2018: Pandeglang In Numbers.

4. Deswimar, D. (2014). Peran Program Pemberdayaan Masyarakat Desa dalam Pembangunan pedesaan. Jurnal El-Riyasah, 5(1), 41-52.

5. Hudaeri, Mohamad. (2003) Tasbih and Golok: Studi Tentang Kharisma Kyai and Jawara di Banten. Jurnal Istiqro. 2(1).

6. Irfani, F., Nafiudin, I., Jamaluddin, W. (2018). Political Jawara of Local Moslem Elits Among Banten Oligarchyi in Indonesia After the New Order Era. JAWI, 1(1). 10.24042/jw. v1i1.3770.

7. Kusumawarta, E. P., Sjaf, S. (2018). Pengorganisasian Komunitas oleh Inovator Pertanian untuk Kesejahteraan Masyarakat. Jurnal JSKPM 2(6), 731-744.

8. Karomani. 2008. Komunikasi elite lokal di banten selatan (Studi Tentang Persepsi and Pengelolaan Kesan Jawara Terhadap Ulama and Umaro). Jurnal Sosiohumaniora. 10(1).

9. Lincoln, G. S. C. Y. S. (2017). Deploying Qualitative Methods for Critical Social Purposes. In Qualitative Inquiry And Social Justice (pp. 53-72). Routledge.

10. Murtagh, F., Pianosi, M., \& Bull, R. (2016). Semantic Mapping Of Discourse And Activity, Using Habermas's Theory of Communicative Action to analyze process. Quality and Quantity, 50(4), 1675-1694.

11. Muslim, A., Kolopaking, L. M., Dharmawan, A. H., Soetarto, E. (2015). Dinamika Peran Sosial Politik Ulama and Jawara di Pandeglang Banten. MIMBAR: Jurnal Sosial and Pembangunan, 31(2), 461-474.

12. Nuris, A. 2016. Tindakan Komunikatif: Sekilas tentang Pemikiran Jürgen Habermas. AlBalagh, 1(1), 39-66.

13. Oktarina, S., Sarwoprasodjo, S. (2018). Strategi Komunikasi Politik Opinion Leader dalam Difusi Program Pembangunan and Pengembangan Lembaga Lokal Di Pedesaan Metacommunication: Journal of Communication Studies, 3(1).

14. Sutisna, A. (2017). Gejala Proliferasi Dinasti Politik di Banten Era Kepemimpinan Gubernur Ratu Atut Chosiyah. Politik Indonesia: Indonesian Political Science Review, 2(2), 100.

15. Tihami, H. M. A. (2012). Dongeng Humor Islami di Pesantren Banten: Sebuah Tela'ah Atas Makna Budaya Dalam Dongeng Humor Di Pesantren Banten. Universitas Islam Negeri Sunan Ampel Surabaya 2012. 1222-1243. 